\title{
Immune response during disease and recovery in the elderly
}

\author{
Bruno Lesourd \\ Unité de Médecine Nutritionnelle Gériatrique, Hôpital Charles Foix, 7 Avenue de la République, 94200 Ivry sur seine, France
}

\begin{abstract}
The present article reviews immune ageing and its relationship with nutritional ageing, with a particular insight into the influences of disease on both ageing processes. Immune ageing can be described primarily as the progressive appearance of immune dysregulations, mainly acquired immunity (mature: immature, naive: memory $\mathrm{T}$ lymphocyte subset decreases) leading to gradual increases in T-helper 2: T-helper 1 cells. This change is due initially to decreased thymic function, and later to accumulative antigen pressure over the lifespan. In contrast, innate immunity (macrophage functions) is preserved during the ageing process and in the elderly this leads to macrophage-lymphocyte dysequilibrium, which is particularly critical during on-going disease. Indeed, any disease induces long-lasting acute-phase reactions in aged patients and leads to body nutritional reserve (mainly protein) losses. Episodes of disease in the aged patient progressively deplete body nutritional reserves and lead to protein-energy malnutrition, undernutritionassociated immunodeficiency, and finally cachexia. Undernutrition is a common symptom in the elderly; protein-energy malnutrition is found in more than $50 \%$ of hospitalized elderly patients and in most elderly diseased subjects. In addition, micronutrient deficit or low levels are common in home-living self-sufficient apparently-healthy elderly subjects. All these nutritional deficits induce decreased immune responses, and micronutrient deficits are now thought to be partly responsible for the decreased immune responses (immune ageing?) observed in the apparentlyhealthy elderly. Indeed, several studies have shown that micronutrient supplements induce increased immune responses in the healthy elderly. The progression of infectious diseases depends on immune responses and on nutritional status before the onset of illness in aged subjects. In addition, recovery depends on the intensity of acute-phase responses in the undernourished elderly. In fact, chronic acute-phase responses, commonly associated with diseases in aged patients, lead to progressive lowering of metabolic responses in the undernourished elderly. This can be quantified by increased production of free radicals during treatment and these increases may explain the difficulty in successfully treating aged patients. Nutritive therapy in order to improve metabolic processes and also to maintain body reserves should be considered as a necessary adjuvant therapy in the treatment of elderly patients.
\end{abstract}

Immune response: Disease: Ageing: Elderly

One of the most important changes for man in the 20th century is a drastic increase in life expectancy. Life expectancy has almost doubled in the last 100 years (Haut Comité de la Santé Publique, 1994). As a consequence, the elderly population is rapidly increasing. In France, the elderly population (>60 years) has grown from $10 \%$ in 1960 to $17 \%$ in 1992, and will continue to increase to comprise onethird of the population by 2030 (Institut National de la Statistique et des Etudes Epidemiologiques, 1995). The present life expectancy at birth is 82.4 years for women and 73.8 years for men (Robine \& Mormiche, 1993). This increase is due to major progress in health-related research in this cen- tury, the most important being hygiene, food supply and preservation, and knowledge of diseases and their treatment. It is important to note that the great majority of 70-year-olds are self-sufficient home-living individuals, in good health; only $5-7 \%$ of the young elderly ( $<80$ years) and less than $15 \%$ of the older elderly ( $>80$ years) live in institutions (nursing homes and/or long-term care facilities) (Commissariat du Plan, 1993). As the elderly population has increased, the cost of retirement pensions and health care has also increased, almost leading to bankruptcy of the social security system. Thus, ageing has become an important subject for research and in the last 20 years ageing has

\footnotetext{
Abbreviations: IFN $\gamma$, interferon $\gamma$, IL, interleukin; PEM, protein-energy malnutrition; PG, prostaglandin; RDA, recommended dietary allowance; TH, T-helper.

Corresponding author: Dr Bruno M. Lesourd, fax +33149594527, email bruno.lesourd@cfx.ap-hop-paris.fr
} 
been studied extensively. Ageing is now better understood, and most present research relates to the study of ageing per se rather than the study of pathological ageing, in order to establish the most important factors relating to ageing and which of these induce accelerated ageing. Environmental factors such as nutrition (Lesourd, 1990a; Feldman, 1993) and infectious diseases (Proust et al. 1985; Nafziger et al. 1993) appear to be major factors influencing immune ageing, which also depends on the genetic background of the individual (Proust et al. 1982; Yong-Xing et al. 1997).

Immune responses, mainly $\mathrm{T}$ lymphocyte function, have been shown to decline with ageing (Makinodan \& Kay, 1980; Goodwin et al. 1982). Many factors have been shown to be involved in the decreased immune responses of the elderly, including decreased thymic function (Tosi et al. 1982; Utsuyama et al. 1997), changes in peripheral $\mathrm{T}$ lymphocyte subpopulations (Deviere et al. 1985; Brohee, 1987) and decreased capacity of peripheral $T$ lymphocytes to be stimulated (Murasko et al. 1986; Hallgren et al. 1988). Environmental factors, particularly nutritional deficit, have also been shown to be involved in the age-related immune deficit, especially in aged patients (Chandra, 1988; Lesourd, $1990 b$; Feldman, 1993). It is only recently that nutritional deficiencies have been thought to have a role in the decreased immune responses of the apparently-healthy elderly. Several investigators have reported that homeliving self-sufficient elderly subjects have low immune responses, probably in relation to low intakes of micronutrients (Payette et al. 1990; Penn et al. 1991; Monget et al. 1996), since supplementation with micronutrients improves immune responses (Talbott et al. 1987; Meydani et al. 1990; Bogden et al. 1994). Furthermore, it has been shown that micronutrient supplementation may lower infection rate in home-living self-sufficient elderly subjects (Chandra, 1992). These findings led Bendich (1990) to suggest that the requirements of the elderly for some micronutrients are higher than those of adults, and to propose that investigations should be carried out into whether immune function should be considered when determining the recommended dietary allowances (RDA) for those nutrients. Furthermore, studies in rodents have shown that the decrease in immune responses may be delayed in dietrestricted animals (Venkatraman et al. 1994; Fernandes et al. 1997). These studies have shown that free radical production due to overfeeding is a major phenomenon in age-related immune deficiency and that diets which lower free radical production delay immune ageing (Venkatraman \& Fernandes, 1994; Fernandes et al. 1997). Finally, we have found that very-carefully-selected healthy elderly subjects, without any micronutrient deficit, do not show decreased immune responses, i.e. normal mitogeninduced $\mathrm{T}$ lymphocyte proliferation and/or interleukin (IL)-2 secretion (Lesourd \& Meaume, 1994; Mazari \& Lesourd, 1998). Since disease induces free radical production and, therefore, decreases immune responses, and as micronutrient deficiency (which is common even in healthy elderly subjects; Wahlquist, 1990; Haller et al. 1996; Lesourd et al. 1998) may lower protection against free radicals, it is obvious that nutritional factors play an important role in immune ageing.
The present paper considers immune responses in elderly patients. First immune responses in healthy elderly subjects will be discussed in order to understand the role of ageing per se in immune responses. Then immune responses will be described in elderly diseased subjects. The role of immune responses on nutritional status in the elderly and on patient outcome will be discussed. Finally, the results of studies on immune function during recovery will be presented to show that nutritional recovery is essential for immune recovery in elderly patients.

\section{Immune responses in aged individuals}

Ageing is associated with increased frequency of disease related to immune dysfunction, i.e. higher incidence of infections (Phair, 1988; Scrimshaw et al. 1988) and of mortality related to infection (Sprenger et al. 1991; McBean et al. 1993), higher levels of monoclonal immunoglobulins (Crawford et al. 1987; Ligthart et al. 1990) and a higher rate of monoclonal gammopathies (Crawford et al. 1987). Initially, ageing was thought to induce a global immunodeficiency (Makinodan \& Kay, 1980; Goodwin et al. 1982). More recently, however, it was established that disease is only partly responsible for the age-related immunodeficiency observed, and a protocol was designed to study the influence of ageing on elderly subjects not affected by disease (Ligthart et al. 1984). In the last 10 years, most of the studies analysing age-related changes in immune responses have conformed to the Senieur (Ligthart et al. 1984) criteria. These findings will be summarized.

Lymphocytes are actively produced daily by bone marrow (billions of lymphocytes each day) and mature in the thymus. Both functions, the ability of stem cells to undergo clonal proliferation (Tyan, 1981) and thymic maturation (Hirokawa et al. 1994), decrease with age. Accordingly, T lymphocyte equilibrium in peripheral blood changes with age; elderly individuals characteristically show increased immature : mature $(\mathrm{CD} 2+\mathrm{CD} 3-$ : $\mathrm{CD} 3+) \mathrm{T}$ cells (Alés-Martinez et al. 1988; Lesourd \& Meaume, 1994) and increased numbers of natural killer cells (CD57+; Ligthart et al. 1986), in relation to increased levels of immature $T$ lymphocytes (Alés-Martinez et al. 1988; Lesourd \& Meaume, 1994). It was even demonstrated in aged mice that a small percentage of peripheral-blood lymphocytes are generated in the liver (Abo, 1992; Nakayama et al. 1994), and the same probably occurs in man (Lesourd et al. 1994). Thus, decreased thymic maturation may be partly compensated by extra-thymic maturation in aged subjects. These changes are of borderline significance in very-carefullyselected healthy elderly (Lesourd et al. 1998; Mazari \& Lesourd, 1998; Table 1) in whom immature T lymphocytes represent only $10-15 \%$ of blood $\mathrm{T}$ lymphocytes. These changes are mainly related to lower numbers of CD8+ subset, while numbers of $\mathrm{CD} 4+$ subset remain virtually unchanged (Lesourd et al. 1994; Lesourd \& Meaume, 1994), even in nonagenarians (Table 1). In addition to decreased numbers of CD8+, peripheral CD8+ have a lower cytotoxic capacity than CD8+ from young adults (Mbawuike et al. 1997). This indicates that age-related changes are due to changes in T-cell subset equilibrium, as well as to the capacities of those subsets, both phenomena 
Table 1. Absolute counts of T-cell subsetsł in peripheral blood of very healthy subjects $\S$

\begin{tabular}{|c|c|c|c|c|c|c|}
\hline \multirow{2}{*}{$n \ldots$} & \multicolumn{2}{|c|}{ Young adults } & \multicolumn{2}{|c|}{$\begin{array}{c}\text { Young elderly } \\
(65-85 \text { years of age }) \\
30\end{array}$} & \multicolumn{2}{|c|}{$\begin{array}{c}\text { Old elderly } \\
\text { (>90 years of age) } \\
16\end{array}$} \\
\hline & Mean & SD & Mean & SD & Mean & SD \\
\hline Age (years) & 29.4 & 3.5 & 77.9 & $5 \cdot 2$ & 94.3 & 3.4 \\
\hline Lymphocytes $\left(/ \mathrm{mm}^{3}\right)$ & 2210 & 470 & 1980 & 620 & $1830^{\star}$ & 680 \\
\hline $\mathrm{CD} 2+\left(/ \mathrm{mm}^{3}\right)$ & 1980 & 310 & $1730^{\star \star *}$ & 410 & $1605^{\star \star}$ & 470 \\
\hline $\mathrm{CD} 3+\left(/ \mathrm{mm}^{3}\right)$ & 1850 & 280 & $1510^{* * *}$ & 320 & $1360^{* *} \dagger$ & 380 \\
\hline $\mathrm{CD} 2+\mathrm{CD} 3-\left(/ \mathrm{mm}^{3}\right)$ & 130 & 130 & $220^{*}$ & 210 & $240^{\star}$ & 250 \\
\hline $\mathrm{CD} 57+\left(/ \mathrm{mm}^{3}\right)$ & 210 & 135 & $390^{\star \star \star}$ & 180 & $430^{\star \star \star}$ & 205 \\
\hline $\mathrm{CD} 4+\left(/ \mathrm{mm}^{3}\right)^{2}$ & 1245 & 190 & $1115^{\star}$ & 260 & $1084^{*}$ & 290 \\
\hline $\mathrm{CD} 8+\left(/ \mathrm{mm}^{3}\right)$ & 670 & 145 & $460^{\star \star \star}$ & 190 & $405^{* \star *}$ & 220 \\
\hline CD45RA $\left(/ \mathrm{mm}^{3}\right)$ & 1230 & 340 & $560^{\star \star \star}$ & 180 & $380^{\star \star \star}+t$ & 200 \\
\hline CD45RO $\left(/ \mathrm{mm}^{3}\right)$ & 760 & 235 & $1090^{\star * *}$ & 420 & $1125^{\star \star \star}$ & 470 \\
\hline
\end{tabular}

CD45RA, naive T lymphocytes; CD45RO, memory T lymphocytes.

Mean values were significantly different from those for the young adults: ${ }^{*} P<0.05,{ }^{* \star} P<0.01,{ }^{* * *} P<0.001$.

Mean values were significantly different from those for the young elderly: $\dagger P<0.05, \dagger+P<0.01$.

$¥$ Quantified on freshly drawn blood, as previously described (Lesourd et al. 1994).

$\S$ Healthy young adults (25-34 years of age) and elderly of different ages were selected according to the SENIEUR protocol (Ligthart et al. 1984$)$ and added criteria (Lesourd et al. 1994; Lesourd \& Meaume, 1994).

contributing to the reported age-related defect in cell-mediated immunity.

The most drastic change in the peripheral-blood T-cell subset is the increase in memory (CD45RO) $\mathrm{T}$ lymphocytes which compensates for the parallel decrease in naive (CD45RA) T lymphocytes. This change in value from 2 to 0.25 for naive : memory $T$ lymphocytes during the lifespan occurs mainly during childhood and early adulthood (Cossarizza et al. 1992), and reflects antigen exposure. However this change continues at a lower rate later in life (Cossarizza et al. 1992) and naive : memory $T$ lymphocytes continues to decrease in later life (Table 1). The aged peripheral microenvironment was found to induce accelerated maturation of $\mathrm{CD} 4 \mathrm{~T}$ lymphocytes from naive to memory cells in aged mice (Thoman, 1997).

The previously described changes have major consequences for lymphocyte functions. Lymphocytes from aged persons are poor IL-2 secretors (Rabinowich et al. 1985; Nagel et al. 1988; Lesourd, 1990a) and show decreased ability to proliferate (Murasko et al. 1987; Nagel et al. 1988; Lesourd, 1990a). Decreased lymphocyte proliferation in aged subjects has been linked to a higher percentage of immature T-cells (Alés-Martinez et al. 1988; Lesourd et al. 1992, 1994) and/or of memory T lymphocytes (Nagelkerken et al. 1991; Hobbs \& Ernst, 1997), both subsets being poor IL-2 secretors. The decrease in lymphocyte proliferation is also due to intrinsic modification of peripheral lymphocytes (Lesourd, 1990a; Miller et al. 1997), e.g. the appearance of new receptors on lymphocyte cell walls after mitogen stimulation is delayed (Lesourd et al. 1992; Wakikawa et al. 1997). Whatever the major cause, T lymphocyte subsets and $\mathrm{T}$ lymphocyte functions have been reported to decrease with ageing. These changes lead to important modifications in cell-mediated immunity, including helper and suppressor functions, cytotoxicity, cytokine secretions, graft rejection and delayed-type hypersensitivity (see Lesourd, 1990a).

The recent progress in cytokine research has revealed separate helper functions for T-helper (TH) 1 and TH2 cells (Mosmann \& Coffman, 1989; Openshaw et al. 1995). Both subsets are activated through different cytokines (Siveke \& Hamann, 1998) and express different functions (Shearer, 1997). TH1 cells are helper cells for cytotoxic T-cells and secrete IL-2, IL-10 and interferon $\gamma$ (IFN $\gamma$ ), while TH 2 cells secrete IL-3, IL-4, IL-6, IL-12 and have helper functions for B lymphocytes. TH1 functions decrease with ageing (decreased IL-2 and IFN $\gamma$ ), while $\mathrm{TH} 2$ functions remain unchanged (comparable with IL-3, IL-4, IL-6; Kubo \& Cinader, 1990; Ershler et al. 1993; Castle et al. 1997; Segal et al. 1997) or may be enhanced (Mbawuike et al. 1997; Table 2). Thus, ageing is now described as immune dysregulation (Weksler, 1995; Cakman et al. 1996) rather than immune deficiency, since some T-cell functions (TH2) remain unchanged or are even increased in aged subjects. However, IFN $\gamma$ does not always show a decrease in aged subjects (Chen et al. 1987; Sindermann et al. 1993), indicating that TH1 functions may also be normal. Since IFN $\gamma$ is also synthesized by memory T-cells (Sanders et al. 1988), which increase with age (Cossarizza et al. 1992), this does not contradict the principle of age-related decreases in THI. More recently, it was reported that IL-2 secretion may also be normal in very-carefully-selected healthy elderly subjects (Gueldner et al. 1997; Mbawuike et al. 1997; Mazari \& Lesourd, 1998), since a similar finding was reported in aged mice, probably in relation to genetic background (Kubo \& Cinader, 1990). It appears, therefore, that immune ageing is mainly influenced by environmental factors, principally nutrition (Lesourd et al. 1998; Mysliwska et al. 1998) and antigenic exposure over the lifespan (Cakman et al. 1996).

Age-related changes in humoral immune responses (B lymphocyte functions) are altogether more subtle, in that immune responses to foreign antigens decline while responses to self antigen increase. Indeed, some B lymphocyte responses are increased in elderly subjects, i.e. levels of immunoglobulins G and A (Batory et al. 1984) and autoantibody levels (Hijmans et al. 1984; Manoussakis et al. 1987). Such increased responses may result from agerelated B-cell subset changes (i.e. increases in CD5+ B lymphocytes; Weksler, 1995), and/or age-related decreases in TH1 : TH2 (Castle et al. 1997; Shearer, 1997; Lesourd 
Table 2. Monocyte cytokine releases in lipopolysaccharide-stimulated culturesł (Mean values and standard deviations)

\begin{tabular}{|c|c|c|c|c|c|c|c|c|}
\hline \multirow[t]{2}{*}{$n \ldots$} & \multicolumn{2}{|c|}{$\begin{array}{c}\text { Young adults§ } \\
36\end{array}$} & \multicolumn{2}{|c|}{$\begin{array}{c}\text { Young elderly§ } \\
24\end{array}$} & \multicolumn{2}{|c|}{$\begin{array}{c}\text { Old elderly§ } \\
11\end{array}$} & \multicolumn{2}{|c|}{$\begin{array}{c}\text { PEM elderly§ } \\
30 \\
\end{array}$} \\
\hline & Mean & SD & Mean & SD & Mean & SD & Mean & $S D$ \\
\hline Age (years) & $29 \cdot 3$ & 3.6 & 78.2 & 4.9 & 94.4 & 3.7 & 84.6 & 7.7 \\
\hline Albumin $(\mathrm{g} / \mathrm{l})$ & $43 \cdot 3$ & 2.9 & $42 \cdot 2 \dagger+\dagger$ & $4 \cdot 1$ & $41 \cdot 3+t t$ & 3.7 & $26 \cdot 3^{* \pm \star}$ & 4.7 \\
\hline $\begin{array}{l}\text { C-reactive protein }(\mathrm{mg} / \mathrm{l}) \\
\text { interleukin-1 (ng/m): }\end{array}$ & \multicolumn{2}{|c|}{$<6$} & \multicolumn{2}{|l|}{$<6$} & \multicolumn{2}{|c|}{$<6$} & $18 \cdot 4$ & 5.9 \\
\hline Spontaneous & ND & & 0.3 & 1.4 & $0.3 \uparrow$ & 1.1 & $2 \cdot 3$ & 3.4 \\
\hline Stimulated & 2.6 & 2.3 & $2.5+t$ & 2.7 & $2 \cdot 8+t$ & 3.0 & $0.9^{* \star \star}$ & 0.9 \\
\hline \multicolumn{9}{|l|}{ Interleukin-6 (ng/ml): } \\
\hline Spontaneous & ND & & ND & & ND & & 0.18 & 0.09 \\
\hline Stimulated & 1.25 & 0.3 & $1.65+† \dagger^{\star \star \star *}$ & 0.4 & $1.8 \dagger \dagger \dagger^{* * *}$ & 0.4 & $0.80^{* * *}$ & 0.35 \\
\hline
\end{tabular}

PEM, protein-energy mainutrition; ND, not detected.

Mean values were significantly different from those for young adults: $* * * P<0.001$.

Mean values were significantly different from those for PEM elderly: $\uparrow P<0.05,+\dagger P<0.01,+\dagger+P<0.001$.

$\ddagger$ Procedures for lipopolysaccharide-stimulated cultures and quantification of supernatant fraction cytokine levels were as previously described (Lesourd et al. 1994). $\S$ Healthy young adults (25-34 years of age) and elderly of different ages were selected according to the SENIEUR protocol (Ligthart et al. 1984) and added criteria (Lesourd et al. 1994; Lesourd \& Meaume, 1994).

et al. 1998; Mysliwska et al. 1998). In contrast, antibody responses to foreign antigens are decreased, mainly primary antibody responses which depend on naive T-cells, while booster responses depending on memory $T$-cells have been shown to be unchanged (Moulias et al. 1985b) or decreased in relation to memory (anti-idiotype) antibodies (Goidl et al. 1983; Arreaza et al. 1993). It appears, therefore, that B lymphocyte responses in elderly subjects are very dependent on T-cell function and environmental factors such as antigenic exposure over the lifespan, which induces decreases in TH1 : TH2 and/or increases in anti-idiotype antibodies. Indeed, once again, nutritional status at the time of antigenic exposure is a major factor influencing B lymphocyte responses (Chandra et al. 1984; Moulias et al. 1985a,b; Lesourd, $1990 a, b)$. With regard to age-related changes in B lymphocyte responses, ageing also appears to induce a dysregulation of immune system.

In contrast to observations relating to lymphocytes, macrophage numbers and function are unchanged or even enhanced in aged animals and human subjects. Monocyte numbers progressively increase with age in mice (Barrat et al. 1997). Antigen-processing ability, as well as IL-1 secretion are comparable in old and young mice (Goldberg et al. 1991). Lipopolysaccharide-activated monocytes from healthy aged subjects release similar levels of IL-1 (Nafziger et al. 1993) and increased levels of IL-6 (Table 2) to those of monocytes from young subjects. Lysosomal activity as well as metabolic burst are maintained in aged subjects (Grigolo et al. 1994). Furthermore, monocyte prostaglandin ( $\mathrm{PG}) \mathrm{E}_{2}$ secretion is increased in aged mice (Hayek et al. 1997). The unchanged and/or enhanced function of monocytes may contribute to the observed dysequilibrium of immune system with ageing. Indeed, lymphocytes from aged individuals are particularly sensitive to $\mathrm{PGE}_{2}$ (Goodwin et al. 1982), which induces lower T-cell function. Increased $\mathrm{PGE}_{2}$ secretion may be partly responsible for decreased T-cell proliferation and/or T-cell IL-2 release (Hayek et al. 1997). Furthermore, $\mathrm{PGE}_{2}$ is also involved in $\mathrm{TH}$ cell function; high $\mathrm{PGE}_{2}$ secretions induce responses in TH2 subset rather than TH1 (Beharka et al. 1997). Furthermore, it has been shown that decreased TH1 function in aged subjects, i.e. decreased CD8+ lymphocyte cytotoxic activity and decreased IFN $\gamma$ secretion, are enhanced by recombinant human IL-12, a pivotal cytokine that stimulates TH1 subset (Mbawuike et al. 1997). Similar findings were observed in mice in which recombinant cytokine treatment is an effective way to reset the agerelated TH1:TH2 changes (Frasca \& Doria, 1997). It appears, therefore, that some of the immune system changes related to ageing are linked to age-related changes in monocyte and/or macrophage functions.

In summary, ageing induces dysequilibriums within cells of the immune system. Cells responsible for innate immunity (i.e. monocytes and macrophages) do not age and are preserved in numbers and functions as long as individuals remain healthy. In contrast, cells responsible for acquired immunity (mainly T lymphocytes, but also to a lesser extent B lymphocytes) do age, and age-related changes induce dysequilibriums within subsets. These changes are dependent on several mechanisms: the decrease in thymic functions (which have almost disappeared at mid-life); environmental (antigenic and diseases) pressures which accumulate over the lifespan. The different ageing modes of the two (innate and acquired) immune systems account for the inability of aged individuals to meet an antigenic challenge.

\section{Immune responses in aged patients}

Immune responses are always decreased in elderly diseased patients. Hallgren et al. (1988) showed that immune variables known to decline with age (i.e. decreased lymphocyte proliferation and decreased mature $C D 3+$ subset) are even lower in elderly diseased subjects. It was subsequently postulated that the decline in immune response in aged subjects is more a reflection of health status than of ageing per se. In our studies of the immune responses in elderly patients, we always found changes in T lymphocyte subsets, including decreased mature CD3+ T-cells, with parallel increases in immature $\mathrm{CD} 2+\mathrm{CD} 3-\mathrm{T}$-cells and natural killer (CD57+) cells, and lower CD8+ and CD4+ T-cells in peripheral blood (Lesourd, 1990b; Lesourd et al. 1992). In addition, the patients always showed low levels of 
Table 3. Changes in $\mathrm{CD} 4+$ subset (CD4+) and of serum soluble interleukin-2 receptor (sIL2-R) in peripheral blood during the progression of lung infections in elderly hospitalized patients† (Mean values and standard deviations)

\begin{tabular}{|c|c|c|c|c|c|c|c|c|c|c|}
\hline \multirow{3}{*}{$\begin{array}{l}\text { Stage of infection ... } \\
\text { Day of investigation . . . }\end{array}$} & \multirow{2}{*}{\multicolumn{2}{|c|}{$\frac{\text { Before infection }}{-5 \text { to }-15}$}} & \multicolumn{4}{|c|}{ During infection } & \multicolumn{4}{|c|}{ During recovery } \\
\hline & & & \multicolumn{2}{|c|}{1} & \multicolumn{2}{|c|}{3} & \multicolumn{2}{|c|}{7} & \multicolumn{2}{|c|}{15} \\
\hline & Mean & SD & Mean & SD & Mean & SD & Mean & so & Mean & SD \\
\hline $\begin{array}{l}\mathrm{CD} 4+\left(/ \mathrm{mm}^{3}\right) \\
\text { slL2-R }(\mathrm{U} / \mathrm{ml})\end{array}$ & $\begin{array}{l}540 \\
125\end{array}$ & $\begin{array}{l}125 \\
140\end{array}$ & $\begin{array}{l}280^{\star \star \star} \\
375^{\star \star \star}\end{array}$ & $\begin{array}{l}110 \\
185\end{array}$ & $\begin{array}{l}220^{\star \star \star} \\
440^{\star \star \star}\end{array}$ & $\begin{array}{r}90 \\
250\end{array}$ & $\begin{array}{l}330^{\star * *} \\
390^{\star *}\end{array}$ & $\begin{array}{l}190 \\
290\end{array}$ & $\begin{array}{l}490 \\
160\end{array}$ & $\begin{array}{l}140 \\
170\end{array}$ \\
\hline
\end{tabular}

Mean values were significantly different from those before onset of infection: ${ }^{\star \star} P<0.01,{ }^{\star \star \star} P<0.001$.

† Elderly hospitalized patients in a convalescent geriatric unit had been monitored continuously for immune responses. Patients ( $n$ 14, 83.7 (SD 7.4 ) years of age) who showed pulmonary infections during their hospital stay were monitored continuously during infection and recovery for CD4+ (Lesourd et al. 1994) and sIL2-R (Gupta, 1986) following routine procedures.

lymphocyte proliferation and low levels of release of $\mathrm{LL}-2$ in mitogen-stimulated cultures (Lesourd, 1990a,b; Lesourd et al. 1992). These immune changes are more pronounced during acute diseases such as infections, which induce decreased lymphocyte numbers in peripheral blood (Proust et al. 1985). These decreases are far less important in adults $(10 \%)$ than in elderly patients $(50 \%)$ during acute pulmonary infections (Proust et al. 1985). Consequently, many elderly subjects with pulmonary infections have lymphopenia $\left(<1000\right.$ lymphocytes $\left./ \mathrm{mm}^{3}\right)$ during the acute phase of the disease. The intensity and the duration of lymphopenia have prognostic value (Proust et al. 1985). The lymphopenia is due to increased lymphocyte destruction at the infection site, and provides an explanation for CD4+ counts being generally lower than $400 / \mathrm{mm}^{3}$ a few days after disease onset (Moulias et al. 1988; Table 3). The increased lymphocyte destruction may be quantified by measuring soluble IL-2 receptor in peripheral blood (Table 3), as shown in patients with acquired immune deficiency syndrome (Gupta, 1986). Elderly patients in whom more lymphocytes are destroyed, have higher serum soluble IL-2 receptor levels and a higher mortality rate (Rosenthal et al. 1997). The intensity of lymphopenia partly results from higher apoptosis of mature (Phelouzat et al. 1996) or immature naive CD45- T lymphocytes (Herndon et al. 1997; Mountz \& Hsu, 1997). Indeed, new $\mathrm{T}$ lymphocytes are recruited to fight infection. If apoptosis is accelerated, as reported by Phelouzat et al. (1996) and Herndon et al. (1997), recruitment of T lymphocytes may be ineffective in elderly patients. In summary, infectious diseases induce lymphopenia in aged patients and therefore induce an immunodeficit or enhance a pre-existing immunodeficiency. The fact that prognosis of the occurrence of infection is related to nutritional status and to immune responses (CD4 counts and lymphocyte proliferation) before infection and at the peak of the infection (Moulias et al. 1993; Lesourd, 1995) indicates the important relationship between nutrition and immunology in aged patients.

Chandra $(1972,1983,1994)$ and Chandra et al. (1984) have shown that protein-energy malnutrition (PEM) decreases immune responses in children (Chandra, 1972, 1994) and also in aged subjects (Chandra, 1983, 1994; Chandra et al. 1984). The effect of PEM on immune responses of elderly patients is linked to the intensity of malnutrition (Lesourd et al. 1992). The same relationships between protein status (i.e. albumin level) and changes in immune $T$ lymphocyte subsets have been observed in apparently-healthy elderly subjects (Lesourd et al. 1994; Lesourd \& Meaume, 1994; Mazari \& Lesourd, 1998); aged individuals with low protein status but otherwise apparently healthy have higher numbers of immature CD2+CD3T lymphocytes and lower phytohaemagglutinin-induced proliferative responses (Lesourd et al. 1994; Lesourd \& Meaume, 1994). Furthermore, they have lower numbers of CD4+ in peripheral blood, an age-related change that is only of borderline significance in healthy elderly subjects with 'normal' protein nutritional status (Lesourd, 1990b; Lesourd \& Meaume, 1994; Mazari \& Lesourd, 1998; Table 1). Agerelated changes in lymphocyte subsets, as observed in very healthy elderly subjects (Mazari \& Lesourd, 1998), are very similar to those observed in healthy elderly subjects showing small decreases in serum protein (Lesourd, 1990a; Lesourd \& Meaume, 1994; Mazari \& Lesourd, 1998), but these changes are more important in the latter group. Similar changes are also observed in elderly diseased subjects, but to a greater extent (Lesourd et al. 1994; Lesourd \& Meaume, 1994). These studies have indicated that lower protein levels are associated with an increase in age-related changes, disease being linked to more important changes in protein levels. Moreover, we have found that decreased lymphocyte proliferation in very-carefully-selected healthy elderly subjects is associated with low folate (erythrocyte and serum) levels (Lesourd \& Meaume, 1994). We reported that healthy elderly subjects without decreased nutritional status and young healthy controls have comparable lymphocyte proliferation (Lesourd \& Meaume, 1994; Mazari \& Lesourd, 1998) and in vitro IL-2 release (Mazari \& Lesourd, 1998), indicating that age-related changes in immune responses may be linked to decreased nutritional status. Other studies have also suggested that immune responses of home-living self-sufficient elderly subjects are decreased in relation to low micronutrient levels (Bogden et al. 1987; Talbott et al. 1987). Several micronutrient deficiencies have been linked to decreased immune responses in healthy elderly subjects, including: antioxidant vitamins (A, E, C; Meydani et al. 1990; Payette et al. 1990; Penn et al. 1991): antioxidant trace elements (Zn, Se; Bogden et al. 1987; Monget, 1992; Boukaiba et al. 1993); vitamins playing a role in cell division (pyridoxine (Talbott et al. 1987); folate (Lesourd et al. 1994)). These findings have been supported by supplementation studies using one micronutrient (Talbott et al. 1987; Meydani et al. 1990; Boukaiba et al. 1993), several micronutrients (Payette et al. 1990; Penn et al. 1991; Monget, 1992) or multi-micronutrient supplementation (Bogden 
et al. 1990; Chandra, 1992; Pike \& Chandra, 1995). In all these studies increased immune responses were observed after long-term supplementation (4-12 months), indicating that immune responses of healthy elderly subjects are lowered when nutritional status is low. Furthermore, one study has shown a reduction in the incidence of infection in home-living self-sufficient elderly subjects in response to multi-vitamin-mineral supplementation (Chandra, 1992). Similar findings have also been reported for institutionalized elderly subjects (Girodon et al. 1997b). From these studies it appears that micronutrient consumption may be too low in many apparently-healthy elderly subjects. We have proposed (Lesourd et al. 1998; Mazari \& Lesourd, 1998), together with others (Mysliwska et al. 1998), that the ageing immune process is strongly influenced by nutritional and health status. Furthermore, it has been suggested that immune responses may be one criterion to be considered in determining RDA of aged subjects (Bendich, 1990).

If immune responses of aged healthy subjects are influenced by low intakes of several micronutrients, even at RDA levels, and/or by deficits of several micronutrients, the influence of nutrition on immune responses of elderly diseased subjects must be important. Indeed, nutritional deficits are common in aged diseased subjects; PEM, which is associated with decreased immune responses (Lesourd, $1990 b$; Lesourd et al. 1992), is present in $50 \%$ of hospitalized elderly subjects (Rudman \& Feller, 1987; Lesourd, $1994)$ and represents the major cause of decreased immune function in elderly subjects (Lesourd \& Meaume, 1994; Lesourd, 1995). The onset of disease promotes both PEM and hospitalization in elderly subjects (Mowe et al. 1994), showing that disease and PEM are strongly correlated in aged subjects. In fact, half the elderly patients entering hospital suffer from PEM (Lesourd, 1994). PEM is always associated with many micronutrient deficits (Johnson, 1990; Wahlquist, 1990; Lesourd, 1994), many of them (e.g. Zn and pyridoxine) inducing immunodeficiency (Meydani et al. 1995 ) or decreased immune responses in healthy elderly subjects (see pp. 89-90 and Lesourd et al. 1998).

Immune responses are decreased markedly in elderly subjects with PEM; compared with healthy elderly subjects, aged patients with serum albumin lower than $30 \mathrm{~g} / \mathrm{l}$ have less than half the number of CD4+ in peripheral blood $\left(<400 / \mathrm{mm}^{3}\right.$ on average) and release one-quarter to half the amount of IL-2 in mitogen-stimulated lymphocyte cultures (Lesourd et al. 1992; Lesourd, 1996; Lesourd \& Mazari, 1997). With severe PEM, in addition to a profound T-cell defect, monocyte functions are also lowered (De la Fuente \& Munoz, 1992; Munoz et al. 1994; Lesourd \& Mazari, 1997; McMurray, 1998); the ability of monocytes to release cytokines (monokine) in lipopolysaccharidestimulated in vitro cultures is decreased (De la Fuente \& Munoz, 1992; Munoz et al. 1994; Lesourd \& Mazari, 1997; Table 2). A similar finding has been reported for mouse monocytes (De la Fuente \& Munoz, 1992). In contrast, tissue macrophages seem to be unchanged in animals with PEM (Filteau \& Hall, 1991; McMurray, 1998), indicating that in situ responses are unchanged. In human subjects mild PEM, as observed in acute infectious diseases, is associated with normal monocyte cytokine release in elderly patients (Cederholm et al. 1997). We have reported that in vitro release of monokine is decreased in patients with PEM (Lesourd \& Mazari, 1997; Tables 2 and 4) but serum cytokines are increased, indicating that in vivo secretion is normal in elderly patients with PEM. In spite of apparentlynormal in vivo secretion of monokine, acute-phase responses induced by such secretions (Klasing, 1988; Lesourd, 1992) are lowered in patients with PEM (Curtis et al. 1995). A strong correlation was established in rats between the intensity of PEM and the magnitude of the acute-phase response (Jennings et al. 1992). The inefficiency of in vivo secretion of monokine has been related

Table 4. Changes in in vivo (serum) and in vitro (supernatant fraction) cytokinest in elderly subjects with protein-energy malnutrition during 2 months of refeeding

(Mean values and standard deviations)

\begin{tabular}{|c|c|c|c|c|c|c|c|c|c|c|c|c|c|c|c|c|}
\hline \multirow{3}{*}{$\begin{array}{l}\text { Period of } \\
\text { refeeding } \\
\text { (d) }\end{array}$} & \multirow{2}{*}{\multicolumn{2}{|c|}{$\begin{array}{l}\text { Albumin } \\
(\mathrm{g} / \mathrm{l})\end{array}$}} & \multirow{2}{*}{\multicolumn{2}{|c|}{$\begin{array}{c}\text { C-reactive pro- } \\
\text { tein (CRP) } \\
\text { (mg/l) }\end{array}$}} & \multicolumn{4}{|c|}{ IL-2 } & \multicolumn{4}{|c|}{ IL-6 } & \multicolumn{4}{|c|}{ IL-1 } \\
\hline & & & & & \multicolumn{2}{|c|}{$\begin{array}{c}\text { Supernatant } \\
\text { fraction } \\
(\mu \mathrm{g} / \mathrm{ml})\end{array}$} & \multicolumn{2}{|c|}{$\begin{array}{l}\text { Serum } \\
(\mu \mathrm{g} / \mathrm{ml})\end{array}$} & \multicolumn{2}{|c|}{$\begin{array}{l}\text { Supernatant } \\
\text { fraction } \\
(\mathrm{ng} / \mathrm{ml})\end{array}$} & \multicolumn{2}{|c|}{$\begin{array}{l}\text { Serum } \\
\text { (pg/ml) }\end{array}$} & \multicolumn{2}{|c|}{$\begin{array}{l}\text { Supernatant } \\
\text { fraction } \\
(\mathrm{ng} / \mathrm{ml})\end{array}$} & \multicolumn{2}{|c|}{$\begin{array}{l}\text { Serum } \\
(\mu \mathrm{g} / \mathrm{ml})\end{array}$} \\
\hline & Mean & $S D$ & Mean & $S D$ & Mean & SD & Mean & SD & Mean & $S D$ & Mean & $S D$ & Mean & SD & Mean & SD \\
\hline $\begin{array}{c}\text { Subjects with low a } \\
0 \\
21 \\
56\end{array}$ & $\begin{array}{l}\text { cute-pha } \\
26.4 \\
29 \cdot 3^{\star} \\
31.5\end{array}$ & $\begin{array}{l}\text { ase re } \\
5.5 \\
4.7 \\
4.4\end{array}$ & $\begin{array}{c}\text { sponses }(C \\
15.3 \\
13.6 \\
11.4^{\star}\end{array}$ & $\begin{array}{l}\text { CRP }< \\
7 \cdot 2 \\
3 \cdot 6 \\
3 \cdot 3\end{array}$ & $\begin{array}{c}30 \mathrm{mg} / \mathrm{l} ; \mathrm{r} \\
0.90 \\
1.16^{\star \star} \\
1.51\end{array}$ & $\begin{array}{l}714) \S \\
0.24 \\
0.22 \\
0.23\end{array}$ & $\begin{array}{l}\text { nd } \\
\text { nd } \\
\text { nd }\end{array}$ & & $\begin{array}{l}0.75 \\
1.03^{\star \star} \\
1.19\end{array}$ & $\begin{array}{l}0.39 \\
0.25 \\
0.26\end{array}$ & $\begin{array}{l}\text { nd } \\
\text { nd } \\
\text { nd }\end{array}$ & & $\begin{array}{l}0.81 \\
1.59^{* *} \\
2 \cdot 71\end{array}$ & $\begin{array}{l}0.74 \\
1.20 \\
1.27\end{array}$ & $\begin{array}{l}\text { nd } \\
\text { nd } \\
\text { nd }\end{array}$ & $\begin{array}{l}d \\
d \\
d\end{array}$ \\
\hline $\begin{array}{c}\text { Subjects with acute } \\
0 \\
21 \\
56\end{array}$ & $\begin{array}{l}\text {-phase } r \\
23.5 \\
24 \cdot 0 \\
28 \cdot 3^{\star \star}\end{array}$ & $\begin{array}{l}\text { espol } \\
5.5 \\
7.3 \\
4.1\end{array}$ & $\begin{array}{l}\text { es (CRP } \\
70.7 \\
40.8^{\star \star \star} \\
15.9\end{array}$ & $\begin{array}{l}<30 \\
33.7 \\
21.2 \\
13.8\end{array}$ & $\begin{array}{c}1 g / l ; n 29) \\
1.07 \\
0.73^{*} \\
1.25\end{array}$ & $\begin{array}{l}\$ \\
0.61 \\
0.35 \\
0.62\end{array}$ & $\begin{array}{c}125 \\
63^{\star} \\
40\end{array}$ & $\begin{array}{r}122 \\
53 \\
36\end{array}$ & $\begin{array}{l}0.91 \\
0.59 \\
1.10\end{array}$ & $\begin{array}{l}0.38 \\
0.74 \\
0.51\end{array}$ & $\begin{array}{l}70 \\
42^{\star \star} \\
7\end{array}$ & $\begin{array}{l}31 \\
30 \\
18\end{array}$ & $\begin{array}{l}0.83 \\
0.87 \\
1.83^{* * *}\end{array}$ & $\begin{array}{l}0.61 \\
0.52 \\
1.18\end{array}$ & $\begin{array}{l}\text { no } \\
\text { nd } \\
\text { nd }\end{array}$ & $\begin{array}{l}\text { d } \\
\text { d } \\
\text { d }\end{array}$ \\
\hline
\end{tabular}

nd, not determined.

Mean values were significantly different from those at day $0:{ }^{\star} P<0.05,{ }^{\star \star} P<0.01, P<0.001$.

$\dagger$ Serum and supernatant fraction (from phytohaemagglutinin-stimulated mononuclear and lipopolysaccharide-stimulated monocyte cultures) were quantified as previously described (Lesourd \& Mazari, 1997; Mazari \& Lesourd, 1998).

$\ddagger$ Intakes at 3 weeks (period required to reach maximal intakes): group with CRP $<30 \mathrm{mg} / \mathrm{l} 160.7$ (SD 33.9$) \mathrm{kJ}(38.4$ (SD 8.1 ) kcal)/kg per d, group with CRP $>30 \mathrm{mg} / 1200$ (SD 25.5) kJ (47.8 (so 6.1) kcal)/kg per d.

$\S$ The two groups (patients with undernutrition in relation to previous undernutrition and patients with undernutrition associated with high acute-phase responses related to on-going disease) were classified according to acute-phase protein levels (Lesourd \& Mazari, 1997). 
to increases in IL-1 receptor antagonist in serum from rats with PEM (Jennings et al. 1992). It may be also related to a $\mathrm{T}$-cell defect in aged patients, since lymphocytes from aged individuals show a reduced reaction to stress signals such as heat-shock proteins (Jurivich et al. 1997). The fact that acute-phase responses are restored in CD2-fas transgenic aged mice (Mountz \& Hsu, 1997) further suggests that a T-cell defect is responsible for the inefficiency of in vivo secretion of monokine. Thus, it appears that the dysequilibrium between monocyte and lymphocyte is of major importance in elderly diseased subjects. Indeed, to stimulate T lymphocytes with decreased functions at an efficient level macrophages must increase their in vivo release of cytokines. However, monokines are not only a major activator of $\mathrm{T}$ lymphocytes, but also play a central role in adjusting body metabolism (Klasing, 1988; Lesourd, 1992) in order to fight disease. IL-1, IL-6 and tumour necrosis factor $\beta$, three major monokines, are directly and/or indirectly (through induced hormonal responses; Carlson \& Little, 1992) responsible for body metabolic changes found in hypermetabolic states. These monokines induce catabolism of body reserves (muscle proteolysis, lipolysis, insulin hyposecretion and bone accretion) in order to provide sufficient macronutrients and $\mathrm{Ca}$ to activate lymphocytes (Lesourd, 1996). In addition, monokines are also responsible for changes in hepatic protein synthesis, including decreases in transport proteins (e.g. albumin) and increases in the synthesis of acute-phase proteins (e.g. C-reactive protein). Monocytes, therefore, exert opposing effects on lymphocytes in PEM, i.e. a boosting effect through direct IL-1 lymphocyte activation and a depressive effect through an IL-1-induced decrease in albumin level to which lymphocytes of aged subjects are especially sensitive. The lower efficacy of monocyte secretions in elderly subjects with PEM, whatever the causes, leads to prolonged monokine secretion and, therefore, to prolonged use of body nutritional reserves. The nutritional effect of prolonged cytokine secretion could have major consequences in the elderly (Cederholm et al. 1997). Ageing is characterized by increased muscle protein catabolism (Fereday et al. 1997) and lower protein synthesis (Welle et al. 1993; Yarasheski et al. 1993), not only at the whole-body level (Young, 1990; Fereday et al. 1997), but also at the cellular level (Welle et al. 1993; Yarasheski et al. 1993). As a consequence, prolonged monokine secretion in aged patients could induce more loss of muscle during on-going disease and less muscle rebuilding during recovery (Lesourd, 1996; Lesourd \& Mazari, 1997). The monocyte-T-cell dysequilibrium which leads to prolonged monokine secretion during on-going disease in the elderly is certainly of importance in the increased sarcopenia observed in aged patients (Roche, 1994; Dutta \& Hadley, 1995).

\section{Immune responses during recovery}

Recently the effects of age and undernutrition on immune responses have been extensively studied, but the changes in immune responses during disease and/or recovery from $P E M$ in aged patients require investigation. Indeed, only a few studies have been carried out in aged patients during long-term or severe illness and during recovery.

We have monitored immune responses in aged patients with lung infections in order to determine which factors may be important for recovery from CD4+ lymphopenia. At the onset of disease patients show a profound immunodeficit, i.e. decreased mature CD3+ T-cells, mostly due to decreased CD4+ in relation to peripheral CD4+ destruction (Moulias et al. 1988; Lesourd, 1990a; Table 3). The decreases in $\mathrm{CD} 3+$ are partly balanced by an increase in immature CD2+CD3- T-cells, mostly due to increases in very immature CD2+CD4-CD8- T-cells (Lesourd, 1993). The increases in this very immature $T$-cell subset confirmed that T-cells destroyed at the periphery are being replaced, but at insufficient levels, since the patient becomes lymphopenic for 3-8d (Proust et al. 1985; Moulias et al. 1988, 1993). At day 3 after the onset of disease, while CD4+ lymphopenia (Table 3) and immature CD2+CD4-CD8CD3-T-cells are at their highest levels (Proust et al. 1985; Moulias et al. 1988, 1993; Lesourd, 1993), a CD2+CD4+CD8+ double positive population develops (Lesourd, 1993). The appearance of the double-positive CD4+CD8+ subset occurs when blood cortisol levels start to decrease (B Lesourd, P Chretien, C Laisney and M Mazari, unpublished results). It is possible that this is related to glucocorticoid responses to lower $\mathrm{T}$-cell replacement in infected aged subjects, since CD4+CD8+ double-positive thymocytes are very sensitive to glucocorticoid-induced apoptosis (Le et al. 1995). Simultaneously, IL-1 production is decreased at the onset of infection (Nafziger et al. 1993), and this decrease may stimulate thymocytes to be more sensitive to glucocorticoid-induced apoptosis (McConkney et al. 1990). The aged-related decrease in the level of thymic hormones (Lewis et al. 1978) may also contribute to the higher sensitivity of thymocytes to glucocorticoid-induced apoptosis (Baumann et al. 1995). The requirement for production of new $\mathrm{T}$ lymphocytes is high in elderly subjects with infection (important peripheral destruction), but bone marrow cell maturation ( $\mathrm{Yu}$ et al. 1997) and thymus functions (Utsuyama et al. 1997) are decreased (which leads to lower T-cell regeneration; Mackall \& Gress, 1997), and thymocyte and naive lymphocyte sensitivity to apoptosis are increased (Herndon et al. 1997; Mountz \& Hsu, 1997). These findings indicate that lymphopenia is far more intense in elderly subjects with infection (Proust et al. 1985) and may contribute to the higher detectable changes in T-cell subsets observed. These changes are probably not seen in younger adult subjects with infection, since the need for $T$-cell replacement is far lower due to lower peripheral lymphocyte destruction, and lymphocyte maturation is greater. Recovery depends on the intensity of lymphopenia at the peak of infection. Not only does mortality depend on the intensity of lymphopenia (Proust et al. 1985; Moulias et al. 1993; Lesourd, 1995) but also on the length of the hospital stay (Moulias et al. 1993) and of lymphopenia recovery (Table 3 ). Thus the aged-related decrease in the ability to compensate for peripheral lymphocyte destruction is of major clinical significance. This has been shown in patients with acquired immune deficiency syndrome; the faster progression of human immunodeficiency virus infection in aged patients (Volberding, 1996) does not 
Table 5. Serum malondialdehyde levels in healthy elderly subjects and in elderly patients with protein-energy malnutrition during refeeding (Mean values and standard deviations for thirteen subjects per group)

\begin{tabular}{|c|c|c|c|c|c|c|c|c|}
\hline & \multicolumn{2}{|c|}{$\begin{array}{l}\text { Healthy elderly } \\
\text { (84.3 (SD 5.2) years) }\end{array}$} & \multicolumn{6}{|c|}{ Undernourished elderly ( 88.4 (SD 5.7) years) } \\
\hline & \multirow[b]{2}{*}{ Mean } & \multirow[b]{2}{*}{ SD } & \multicolumn{2}{|c|}{ Day 0 (on admission) } & \multicolumn{2}{|c|}{ Day 21} & \multicolumn{2}{|c|}{ Day 42} \\
\hline & & & Mean & SD & Mean & SD & Mean & SD \\
\hline $\begin{array}{r}\text { Energy intake: } \mathrm{kJ} / \mathrm{kg} \text { per d } \\
\mathrm{kcal} / \mathrm{kg} \text { per d }\end{array}$ & & & $\begin{array}{l}78.3 \\
18.7\end{array}$ & $\begin{array}{r}18 \cdot 0 \\
4.3\end{array}$ & $\begin{array}{r}135 \cdot 6 \\
32 \cdot 4\end{array}$ & $\begin{array}{r}39.3 \\
9.4\end{array}$ & $\begin{array}{r}148.1 \\
35.4\end{array}$ & $\begin{array}{r}17.6 \\
4.2\end{array}$ \\
\hline Body wt (kg) & 54.7 & $10 \cdot 4$ & $44 \cdot 6^{\star \star}$ & 9.2 & 44.8 & 9.7 & $46 \cdot 8$ & 9.3 \\
\hline Albumin $(\mathrm{g} /)$ & 42.4 & $2 \cdot 1$ & $29 \cdot 8^{\star \star \star}$ & 5.7 & 31.7 & $6 \cdot 4$ & $34.7 \dagger$ & 5.1 \\
\hline C-reactive protein $(\mathrm{mg} / \mathrm{l})$ & & & 29 & 31 & $11+$ & 17 & $7+t$ & 4 \\
\hline Malondialdehyde (mmol/l) & 0.59 & 0.43 & $1 \cdot 28^{\star \star \star}$ & 0.40 & $1.70+t$ & 0.45 & $1.65 \dagger$ & 0.48 \\
\hline
\end{tabular}

Mean values were significantly different from those for the healthy elderly: ${ }^{\star \star} P<0.01,{ }^{\star \star \star} P<0.0001$.

Mean values were significantly different from those for Day $0: \dagger P<0.05, \dagger \dagger P<0.02$.

$\ddagger$ Peroxidation measured as serum malondialdehyde levels (Monget, 1992; Monget et al. 1996).

appear to be due to greater destruction of lymphocytes, but rather to an inability of older individuals to replace destroyed functional T-cells (Adler et al. 1997). We had shown that adjuvant treatment of infections with an immunomodulator drug may hasten recovery (Lesourd et al. 1987). In a double-blind placebo controlled study, treatment with Imuthiol ${ }^{\circledR}$ (Merieux Institute, Lyon, France) leads to a faster decrease in fever, in clinical signs and in lymphopenia recovery. This drug is known to facilitate thymocyte maturation (Pompidou et al. 1985). In our study lymphopenia and neutropenia recoveries were strongly correlated with decreases in the clinical signs. Consequently, we believe that the ability to replace destroyed lymphocytes is one of the major factors influencing recovery from infection in aged patients, and this depends on the effect of age on lymphocyte maturation.

Nutrition does exert a major influence on immune responses in aged subjects (see pp. 89-90). We have tried to measure the influence of nutrition on the recovery of aged patients with PEM treated for undernutrition. However, both nutrition and disease influence the observed effects. We investigated two different types of undernourished elderly subjects during nutritive therapy: patients with undernutrition in relation to previous undernourishment; patients with undemutrition associated with high acute-phase responses related to on-going disease. The classification of the two groups was based on acute-phase protein levels, i.e. C-reactive protein ( $>$ or $<30 \mathrm{mg} / 1$ ) and $\alpha-1$ glycoprotein acid $(>1.4 \mathrm{~g} / 1$ or $<1.0 \mathrm{~g} / 1$ ); Lesourd \& Mazari, 1997). The two groups were followed for 3 weeks, the period required to reach maximal intakes in our experiment, and then for a further 5 weeks to quantify the effects of refeeding on immune responses. Refeeding improved the immune responses of undernourished elderly subjects, but in a different manner with regard to the levels of acutephase responses (Table 4). In undernourished patients with low acute-phase responses, we were unable to detect any cytokines in the serum. Refeeding induced improved secretion of cytokine in in vitro cultures, not only in phytohaemagglutinin-activated lymphocyte cultures (IL-2) but also in lipopolysaccharide-activated monocyte cultures (IL1 and IL-6; Table 4). This effect was highly correlated with increases in serum albumin. In contrast, the immune effect of refeeding required longer-term nutritive therapy to be quantifiable in aged patients with high acute-phase responses. In these patients in vivo activation of the immune system was evident, since serum cytokines could be quantified at the onset of treatment. Furthermore, supernatant fractions from cell cultures had lower cytokine contents after 3 weeks of nutritive therapy (Table 4). At this stage, serum albumin was unchanged even though there was a decrease in serum acute-phase proteins, which were still at high levels (CRP $>30 \mathrm{mg} / \mathrm{l}$, on average). Subsequently, when acute-phase responses had further decreased (CRP $<30 \mathrm{mg} / \mathrm{l}$ for approximately all subjects), serum albumin levels and the release of cytokine from cell cultures were increased. This finding indicates that immune responses only increase in undernourished elderly subjects when nutritive therapy is effective, as assessed by serum albumin levels. Furthermore, the number of patients who died during the study was low (data not shown). In those who died neither serum albumin nor in vitro cytokine from cultures of the supernatant fraction increased but, in contrast, they decreased. Moreover, in vivo serum cytokines also decreased, indicating that patients were no longer able to fight on-going disease or to boost their immune system in vivo. The fact that acute-phase responses remained unchanged and/or decreased in dying patients indicates that they had reached a state where they had exhausted their metabolic capacities.

In another study, we quantified malondialdehyde, a product of lipid peroxidation, in patients with PEM receiving nutritive therapy. Malondialdehyde levels were increased in elderly subjects with PEM as compared with healthy aged controls (Table 5). During refeeding treatment which provided 1- to 2-fold RDA for each antioxidant micronutrient (vitamins $\mathrm{A}, \mathrm{C}$ and $\mathrm{E}, \mathrm{Zn}$ and Se) for $40 \mathrm{~d}$, malondialdehyde levels increased and remained high compared with initial levels. Refeeding therefore induced increased free radical production in elderly subjects with PEM. This increase was limited before nutritive therapy in patients with PEM, probably in relation to a PEMinduced decrease in metabolic capacity. When refeeding provided enough nutrients to boost metabolism processes, then metabolism and consequently free radical production increased. Providing antioxidants at RDA levels is inadequate to protect against the increased free radical production due to the boost in metabolism in elderly subjects with 
PEM, while RDA levels are sufficient in children (Khaled et al. 1995). In elderly patients hospitalized in long-stay units, it has been shown that providing antioxidant micronutrients at a similar level (1- to 3-fold RDA) leads to an increase in plasma micronutrient levels (Monget, 1992; Galan et al. 1994; Girodon et al. 1997a) and to lower malondialdehyde levels (Monget, 1992; Galan et al. 1994; Girodon et al. 1997a), but this treatment needs to be of longer duration (at least 6 months; Monget, 1992) and does not induce increased immune responses (Girodon et al. 1997a). The increased sensitivity to free radicals of elderly subjects with PEM and/or disease may be one of the factors limiting successful treatment. Free radicals induce decreased immune responses (Kehrer \& Smith, 1994; Harman, 1995). This may be the key factor in explaining why immune responses in elderly subjects with PEM and inflammation improve slowly.

Ageing is partly due to free radical damage accumulated over the lifespan (Lang et al. 1992; Harman, 1995; Meydani et al. 1995). Any disease induces increases in metabolic processes and therefore increases free radical production (Kehrer \& Smith, 1994; Scarfiotti et al. 1997) leading to cell damage. Diseases represent a form of accelerated ageing termed pathological ageing. Repeated episodes of infectious diseases, which occur in acquired immune deficiency syndrome (Allard et al. 1998), have a similar effect, and promote accelerated ageing of the immune system (Scarfiotti et al. 1997), as shown by changes in TH1 : TH2 (Lucey et al. 1996). Such changes were observed in acquired immune deficiency syndrome (Clerici \& Shearer, 1994; Lee et al. 1998) and in Down's syndrome (Cosarrizza et al. 1991), two forms of accelerated ageing of the immune system (Cosarrizza et al. 1991; Clerici \& Shearer, 1994). In both cases a change in helper immune responses from $\mathrm{TH} 1$ to $\mathrm{TH} 2$ was observed, a similar phenomenon to that observed in immune ageing (Shearer, 1997). The difference we observed during an episode of disease was the greater sensitivity of elderly subjects to free radical damage, which reveals an apparent inability to protect themselves from exposure to free radicals. It may be considered necessary to treat elderly diseased subjects with high levels of antioxidant micronutrients in order to protect cells from free radical damage. Higher levels than the present RDA have been proposed (Bendich, 1990) to prevent 'normal' ageing. This type of treatment may be of long duration, since stress responses are of long duration in aged patients (Hayek et al. 1997; Jurivich et al. 1997). The macrophage is now thought to be a key cell in immune ageing in relation to free radical production. It was recently shown that macrophage PG contributes to the ageassociated decrease in T-cell function (Hayek et al. 1997). This effect is important in aged subjects due to high levels of macrophage $\mathrm{PGE}_{2}$ production and the increased sensitivity to $\mathrm{PGE}_{2}$ of lymphocytes from aged subjects (Goodwin et al. 1982). Antioxidant treatment with high vitamin $\mathrm{E}$ intakes reverses high $\mathrm{PGE}_{2}$ production and partly restores immune functions (Beharka et al. 1997), and further points to the importance of macrophages and free radicals in immune ageing. Furthermore, in rodent models energy restriction, which decreases free radical production (Venkatraman \& Fernandes, 1994), inhibits the age-related dysregulation in cytokine production (Spaulding et al. 1997).

\section{Conclusion}

Ageing of the immune system is characterized by the appearance of progressive dysregulation between different functions of the immune system. With ageing there are gradual increases in immature: mature, memory : naive, $T$ lymphocyte TH1:TH2 and B lymphocyte CD5+:CD5-. These changes are induced by two main factors, i.e. decreased thymic function, and antigenic pressures over the lifespan. These changes are important during early life (up to 30-40 years of age in human subjects), a period which is important in acquiring adapted immune responses against foreign antigens. Nevertheless, similar changes in immune responses continue with age, but at a lower rate. Ageing is also characterized (mainly in the second half of life) by a progressive dysregulation between monocyte function (which is unchanged) and lymphocyte function (which decreases). It appears that acquired immunity weakens with age, probably because its adaptive capacity is limited by its own regulation, while innate immunity, a more primitive system, is unchanged.

Ageing is well-known to be associated with lower adaptive capacities. This is true for acquired immunity, not only in facing antigenic challenges but also in relation to metabolic changes such as those resulting from underfeeding and/or nutritional responses to disease (hypercatabolism syndrome). Aged subjects are particularly sensitive to nutritional influences, and any nutritional deficit (i.e. energy, protein or even micronutrient) may lower the immune responses of the elderly. As nutritional deficits are frequent in diseased subjects, many, if not all, elderly diseased subjects exhibit decreased immune response and a lower capacity to fight disease. Furthermore, micronutrient deficits are also frequent in the elderly, and some of the age-related change in immune response may be due to lower nutritional status. The declines in nutritional status and in immune response with age are interrelated. The lower capacity of the elderly to fight disease partly results from the dysregulation of the immune system, i.e. from the dysequilibrium between macrophage function (innate immunity) and lymphocyte function (acquired immunity). This dysequilibrium forces macrophages to play a more intense role in defence mechanisms of the elderly, i.e. to secrete more cytokines. Consequently, acute-phase responses are more intense and/or of longer duration in the elderly, leading to greater use of body nutritional reserves. Furthermore, the age-related decrease in metabolism is responsible for incomplete rebuilding of nutritional reserves during recovery. In the absence of nutritional treatment (which is necessary to help the elderly respond to the nutritional consequences of diseases) after recovery, the elderly have lower body reserves and lower immune responses. As a result of successive bouts of disease, the elderly progressively become frail. Nutritional therapy must be given to all elderly patients for both the duration of the disease and throughout the recovery period (which is of longer duration in aged patients). In addition, it may be necessary to consider higher micronutrient intakes in apparently-healthy elderly subjects, either to boost immune responses or to prevent a decline in immune response. 


\section{References}

Abo T (1992) Extrathymic differentiation of $T$ lymphocytes and its biological function. Biology in Medical Research 13, 139.

Adler WH, Baskar PV, Chrest FJ, Dorsey-Cooper B, Winchurch RA \& Nagel JE (1997) HIV infection and ageing: mechanisms to explain the accelerated rate of progression in the older patient. Mechanism of Ageing and Development 96, 137-155.

Alès-Martinez JE, Alvarez-Mon $M$, Merino $F$, Boniilla $F$, Martinez-Alés C, Durantez A \& De La Hera A (1988) Decreased TcR-CD3- T cell numbers in healthy aged humans. Evidence that $T$ cell defects are masked by a reciprocal increase of $T c R$ CD3- CD2+ natural killer cells. European Journal of Immunology 18, 1827-1830.

Allard JP, Aghdassi E, Chau J, Salit I \& Walmsley S (1998) Oxidative stress and plasma antioxidant micronutrients in humans with HIV infection. American Journal of Clinical Nutrition 67, 143-147.

Arreaza EE, Gibbons JJ, Sisking GW \& Weksler ME (1993) Lower antibody response to tetanus toxoid associated with higher autoanti-idiotype antibody in old compared with young humans. Clinical Experimental Immunology 92, 169-176.

Barrat F, Lesourd BM, Louise A, Boulouis HJ, Vincent-Naulleau S, Thibault D, Neway T, Sanaa M \& Pilet Ch (1997) Surface antigens expression in spleen cells of $\mathrm{C} 57 \mathrm{BL} / 6$ mice during aging: influence of sex and breeding. Clinical Experimental Immunology 107, 593-600.

Batory G, Janeso A, Puskas E, Redei A \& Lengyei E (1984) Antibody and immunoglobulin levels in aged humans. Archives of Gerontology and Geriatrics 3, 175-188.

Baumann C, Badamchiam M \& Goldstein AL (1995) Thymosin $\alpha 1$ antagonizes induced apoptosis of developing thymocytes in vitro. Molecular Cell Biology 6, 356a.

Beharka AA, Wu D, Han SN \& Meydani SN (1997) Macrophage prostaglandin production contributes to the age-associated decrease in $\mathrm{T}$ cell function which is reversed by the dietary antioxidant vitamin E. Mechanism of Ageing and Development 96, 203-208.

Bendich A (1990) Antioxidant micronutrient and immune responses. Annals of the New York Academy of Sciences 587, 168-180.

Bogden JD, Bendich A, Kemp FW, Bruening KS, Shurrick JH, Denny T, Baker H \& Louria DB (1994) Daily micronutrient supplements enhance delayed-hypersensitivity skin test responses in older people. American Journal of Clinical Nutrition 60, 437-447.

Bogden JD, Oleske JM, Lavenhar MA, Munves EM, Kemp FW, Bruening KS, Holding KJ, Denny TN, Guarino MA \& Holland BK (1990) Effects of one year of supplementation with zinc and other micronutrients on cellular immunity in the elderly. Journal of the American College of Nutrition 9, 214 225.

Bogden JD, Oleske JM, Munves EM, Lavenhar MA, Bruening KS, Kemp FW, Holding KJ, Denny TN \& Louria DB (1987) Zinc and immunocompetence in the elderly: baseline data on zinc nutriture and immunity in unsupplemented subjects. American Journal of Clinical Nutrition 45, 101-109.

Boukaiba N, Flament C, Acher S, Chappuis Ph, Pian A, Fusselier M, Dardenne M \& Lemonnier D (1993) A physiological amount of zinc supplementation: effects on nutritional, lipid, and thymic status in an elderly population. American Journal of Clinical Nutrition 57, 566-572.

Brohee D (1987) Age et sous-populations lymphocytaires: analyse critique de la litterature (Ageing and lymphocyte subsets: critical analysis of the literature). Revue de Gériatrie 12, 199-203.
Cakman I, Rohwer J, Schûtz RM, Kirchner H \& Rink L (1996) Dysregulation between $\mathrm{TH} 1$ and TH2 cell sub-populations in the elderly. Mechanism of Ageing and Development 87, 197-209.

Carlson GL \& Little RA (1992) The pathophysiology and pattern of the hormonal response to severe sepsis. In Conséquences Endocriniennes des États d'Agression Aigue: Collection Perspectives en Réanimation (Endocrine Consequences of Acute States: an Overview), pp. 57-68 [JM Bowles, editor]. Paris: Arnette.

Castle S, Uyemura K, Wong W, Modlin R \& Effros R (1997) Evidence of enhanced type 2 immune response and impaired upregulation of a type 1 response in frail elderly nursing home residents. Mechanism of Ageing and Development 94, 7-16.

Cederholm T, Wretlind B, Hellstrom K, Andersson B, Engstrom L, Brismar K, Scheynius A, Forslid J \& Palmblad J (1997) Enhanced generation of interleukins $1 \beta$ and 6 may contribute to the cachexia of chronic disease. American Journal of Clinical Nutrition 65, 876-882.

Chandra RK (1972) Immunocompetence in undernutrition. Journat of Pediatrics 81, 1194-1200.

Chandra RK (1983) Numerical and functional deficiency in $T$ helper cells in protein energy malnutrition. Clinical Experimental Immunology 51, 126-132.

Chandra RK (1988) Nutrition, immunity and outcome; past, present and future. 11th Gopalan Gold Medal Oration. Nutrition Research 8, 225-237.

Chandra RK (1992) Effect of vitamin and trace-element supplementation on immune responses and infection in elderly subjects. Lancet 340, 1124-1127.

Chandra RK (1994) Nutritional regulation of immune function at the extremes of life: in infants and in the elderly. In Malnutrition Determinants and Consequences, pp. 245-251 [P White, editor]. New York: Alan R. Liss.

Chandra RK, Chandra S \& Gupta S (1984) Antibody affinity and immune complexes after immunization with tetanus toxoid in protein-energy malnutrition. American Journal of Clinical Nutrition 40, 131-134.

Chen WF, Liu SL, Gao XM \& Pang XI (1987) The capacity of lymphokine production by peripheral blood lymphocytes from aged humans. Immunology Investigation 15, 575-583.

Clerici M \& Shearer GM (1994) The Th1/Th2 hypothesis of HIV infection: new insights. Immunology Today 15, 575-581.

Commissariat Général du Plan (1993) Santé 2010 - Groupe Prospective du Système de Santé (Health 2010; A Report from the Public Health System Prospective Group). Paris: La Documentation Française.

Cossarizza A, Ortolani C, Forti E, Montagnani G, Paganelli R, Zanotti M, Marini M, Monti D \& Franceschi C (1991) Agerelated expansion of functionally inefficient cells with markers of natural killer activity in Down's syndrome. Blood 77, 12631270.

Cossarizza A, Ortolani C, Paganelli R, Monti D, Barbieri D, Sansoni P, Fagiolo U, Forti E, Londei M \& Franceschi C (1992) Age-related imbalance of virgin (CD45RA+) and memory (CD45RO+) cells between CD4+ and CD8+ $\mathrm{T}$ lymphocytes in humans: study from newborns to centenarians. Journal of Immunology Research 4, 117-126.

Crawford J, Eye MK \& Cohen HJ (1987) Evaluation of monoclonal gammopathies in the well elderly. American Journal of Medicine 82, 39-45.

Curtis GE, McAtear CA, Formela L, Walsh A \& Shenkin A (1995) The effect of nutritional status on the cytokine and acute phase protein responses to elective surgery. Cytokine 7,380 388.

De la Fuente M \& Munoz ML (1992) Impairment of phagocytic process in macrophages from young and old mice by protein malnutrition. Annals of Nutrition and Metabolism 36, 41-47. 
Deviere J, Kennes B, Giosset J, De Maertelaer V \& Neve P (1985) Immune senescence: effect of age, sex and health on human blood mononuclear subpopulations. Archives of Gerontology and Geriatrics 4, 285-293.

Dutta C \& Hadley EC (1995) The significance of sarcopenia in old age. Journal of Gerontology 50, 1-4.

Ershler WB, Sun WH, Binkley N, Gravenstein S, Volk MJ, Kamoske G, Kloop RG, Roecker EB, Daynes RA \& Weindruch $\mathrm{R}$ (1993) Interleukin-6 and aging: blood levels and mononuclear cell production increase with advancing age and in vitro production modifiable by dietary restriction. Lymphokine and Cytokine Research 12, 225-230.

Feldman EB (1993) Aspects of the interrelations of nutrition and aging: perspective. American Journal of Clinical Nutrition 58, $1-3$.

Fereday A, Gibson NR, Cox M, Pacy PJ \& Millward DJ (1997) Protein requirements and ageing: metabolic demand and efficiency of utilization. British Journal of Nutrition 77, 685702.

Fernandes G, Venkatraman JT, Turturro A, Attwood VG \& Hart RW (1997) Effect of food restriction on lifespan and immune functions in long-lived Fischer- $344 \times$ Brown Normay F1 Rats. Journal of Clinical Immunology 17, 85-95.

Filteau SM \& Hall NRS (1991) Increased production of tumor necrosis factor and interleukin 1 by peritoneal macrophages from severely undernourished mice: lack of correlation with serum corticosterone. Nutrition Research 11, 1001-1011.

Frasca D \& Doria G (1997) Recombinant cytokines as an approach to immune reconstitution in aging. Developmental and Comparative Immunology 21, 525-530.

Galan P, Preziosi P, Richard MJ, Monget AL, Arnaud J, Lesourd B, Favier A, Girodon F, Laisney C, Bourgeois CF, Keller H, Hercberg S \& Le Réseau Gériatrie/MIN.VIT.AOX (1994) Biological and immunological effects of trace element and/or vitamin supplementation in the elderly. Proceedings of the 4th International Conference on Trace Elements in Medicine and Biology, pp. 197-210.

Girodon F, Blache D, Monget AL, Lombart M, Brunet-Lecompte P, Arnaud J, Richard MJ \& Galan P (1997a) Effect of a two-year supplementation with low doses of antioxidant vitamins and/or minerals in elderly subjects on levels of nutrients and antioxidant defense parameters. Journal of the American College of Nutrition 4, 357-365.

Girodon F, Lombard M, Galan P, Brunet-Lecomte P, Monget AL, Arnaud J, Preziosi P \& Hercberg S (1997b) Effect of micronutrient supplementation on infection in institutionalized elderly subjects: a controlled trial. Annals of Nutrition and Metabolism 41, 98-107.

Goidl EA, Chov JW, Gibbons JJ, Wekler ME, Thorbecke GJ \& Siskind GW (1983) Production of auto anti-idiotypic antibody during the normal auto-anti-idiotype antibody production by aged mice. Joumal of Experimental Medicine 57, $635-645$.

Goldberg TH, Baker DG \& Shumacher HR (1991) Interleukin-1 and the immunology of aging and disease. Aging, Immunology and Infectious Diseases 3, 81-86.

Goodwin JS, Searles RP \& Tung KSK (1982) Immunological responses of a healthy population. Clinical Experimental Immunology 48, 403-410.

Grigolo B, Borzi RM, Mariani E, Monaco CM, Cattini L, Porstmann T \& Facchini A (1994) Intracellular $\mathrm{Cu} / \mathrm{Zn}$ superoxide dismutase levels in $\mathrm{T}$ and non- $\mathrm{T}$ cells from normal aged subjects. Mechanism of Ageing and Development 73, 27-37.

Gueldner SH, Poon LW, La Via M, Virella G, Michel Y, Bramlett MH, Noble CA \& Paulling E (1997) Long term exercise patterns and immune function in healthy older women: a report of preliminary findings. Mechanism of Ageing and Development 96, 215-222.

Gupta S (1986) Study of activated T cells in man. II. Interleukin 2 receptor and transferrin receptor expression on $T$ cells and production of interleukin 2 in patients with the acquired immune deficiency syndrome (AIDS) and AIDS-related complex. Clinical Immunology and Immunopathology 38, 93-100.

Haller J, Weggemans RM, Lammi-Keefe CJ \& Ferry M (1996) Changes in the vitamin status of elderly Europeans: plasma vitamins A, E, B-6, B-12, folic acid and carotenoids. European Joumal of Clinical Nutrition 50, Suppl. 2, S32-S46.

Hallgren HM, Bergh N, Rodysill KJ \& O'Leary JJ (1988) Lymphocyte proliferation responses to PHA and Anti CD3/Ti monoclonal antibodies, $\mathrm{T}$ cells surface marker expression and serum IL2 receptor levels as biomarkers of age and health. Mechanism of Ageing and Development 43, 175-185.

Harman D (1995) Role of antioxidant nutrients in aging: overview. Age 18, 51-62.

Haut Comité de la Santé Publique (1994) La Santé en France. Rapport Général. (Health Status in France. A General Report). La Documentation Française, November.

Hayek GM, Mura C, Wu D, Beharka AA, Han SN, Paulson E, Hwang D \& Meydani SN (1997) Enhanced expression of inducible cyclooxygenase with age in murine macrophages. Joumal of Immunology 159, 2445-2451.

Herndon FJ, Hsu HC \& Mountz JD (1997) Increased apoptosis of $\mathrm{CD}^{2} 5 \mathrm{RO}^{-} \mathrm{T}$ cells with ageing. Mechanism of Ageing and Development 94, 123-134.

Hijmans W, Radl J, Bottazo GF \& Doniach D (1984) Autoantibodies in highly aged humans. Mechanism of Ageing and Development 26, 33-39.

Hirokawa K, Utsuyama M, Kasai M, Kurishima C, Ishijima S \& Zeng YX (1994) Understanding the mechanisms of the age changes of thymic function to promote $\mathrm{T}$ cell differentiation. Immunology Letters 40, 269-277.

Hobbs MV \& Ernst DN (1997) T cell differentiation and cytokine expression in late life. Developmental and Comparative Immunology 21, 464-470.

Institut National de la Statistique et des Etudes Epidémiologiques (1995) Projection de Population Totale pour la France Métropolitaine 1990 (Perspective Projection for the French Population in 1990). INSEE Publication no. 412, pp. 22-25. Paris: INSEE.

Jennings G, Bourgeois C \& Elia M (1992) The magnitude of the acute phase protein response is attenuated by protein deficiency in rats. Journal of Nutrition 122, 1325-1351.

Johnson LE (1990) Vitamin disorders in the elderly. In Geriatric Nutrition, 1st ed., pp. 117-147 [JE Morley, Z Glick and LZ Rubinstein, editors]. New York: Raven Press.

Jurivich DA, Qiu L \& Welk JF (1997) Attenuated stress responses in young and old human lymphocytes. Mechanism of Ageing and Development 94, 23-249.

Kehrer JP \& Smith CB (1994) Free radicals in biology: sources, reactivities and roles in the etiology of human diseases. In Natural Antioxidants in Human Health and Diseases, pp. 25-62. New York: Academic Press.

Khaled MA, Kabir I \& Mahalanabis D (1995) Effect of protein energy supplementation on oxidative stress in malnourished children. Nutrition Research 15, 1099-1104.

Klasing KC (1988) Nutritional aspects of leukocyte cytokines: critical review. Journal of Nutrition 11, 1436-1446.

Kubo M \& Cinader B (1990) Polymorphism of age-related changes in interleukin (IL) production: differential changes of $\mathrm{T}$ helper subpopulation, synthesizing IL-2, IL-3, and IL-4. European Journal of Immunology 24, 133-136. 
Lang GA, Naryshkin S, Schneider DL, Mills BJ \& Lindeman RD (1992) Low blood glutathione levels in healthy aging adults. Journal of Laboratory and Clinical Medicine 120, 720-725.

Le PH, Macker HT \& Cook JE (1995) In situ detection and characterization of apoptotic thymocytes in human thymus. Journal of Immunology 154, 4371-4378.

Lee J, Jiang B, Inserra P, Zhang Z, Solkoff D \& Watson RR (1998) Antioxidant supplementation in prevention and treatment of immune dysfunction and oxidation induced by murine AIDS in old mice. Nutrition Research 18, 327-339.

Lesourd B (1990a) Le vieillissement immunologique: influence de la dénutrition (Immune ageing: the effect of malnutrition). Annales de Biologie Clinique 48, 309-318.

Lesourd B (1990b) La dénutrition protéique: principale cause de déficit immunitaire chez le sujet âgé (Protein-energy malnutrition: the main cause of immunodeficiency in the elderly). Age and Nutrition 1, 132-138.

Lesourd B (1992) Conséquences nutritionnelles des cytokines: facteur de gravité des hypercatabolismes chez le sujet âgé (Nutritional consequences of cytokine secretion: a prognosis factor of hypercatabolism in elderly). Age and Nutrition 3, 100109.

Lesourd B (1993) Nutrition, immunité et vieillissement chez l'homme. Interférences nutritionnelles sur le vieillissement immunitaire humain normal et pathologique (Nutrition, immunity and ageing in human beings. Nutritional influences on immune ageing in healthy and diseased elderly). PhD Thesis. Université Paris VI.

Lesourd BM (1994) La malnutrition protéino-énergétique chez les sujets âgés (Protein-energy malnutrition in aged persons). Semaines des Hôpitaux de Paris 70, 957-963.

Lesourd BM (1995) Protein undernutrition as the major cause of decreased immune function in the elderly: clinical and functional implications. Nutrition Reviews 53, S86-S94.

Lesourd BM (1996) Hypermetabolism: a frightening symptom that pushes elderly to enter a vicious circle. In Vitality Mortality and Ageing, Ageing Series no. 5, pp. 363-376 [A Viidik and G Hofecker, editor]. Vienna: Facultas Universitäts Verlag Wien.

Lesourd B, Congy F, Nafziger J, Salvatore R, Deslandes D \& Moulias R (1987) L'imuthiol en gériatrie. Influences sur la réponse à la vaccination grippale et sur les infections sévères lymphopéniantes (Imuthiol therapy in geriatrics. Influences on flu vaccine responses and on acute lymphopenic infections). Proceedings des Journées de l'Hôpital Claude Bernard. In Immunomodulateurs et Thérapeutique AntiInfectieuse (Immunodulators and Anti-infection Therapy), pp. 47-51 [JJ Pocidalo, JP Coulaud, F Vachon and JL Vilde, editors]. Arnette.

Lesourd B, Laisney C, Salvatore R, Meaume S \& Moulias R (1994) Decreased maturation of $T$ cell population factors on the appearance of double negative CD4-, CD8-, CD2+ cells. Archives of Gerontology and Geriatrics 4, Suppl., 139-154.

Lesourd BM \& Mazari L (1997) Immune responses during recovery from protein-energy malnutrition. Clinical Nutrition 16, Suppl. 1, 37-46.

Lesourd BM, Mazari L \& Ferry M (1998) The role of nutrition in immunity in the aged. Nutrition Reviews 56, S113-S125.

Lesourd B \& Meaume S (1994) Cell-mediated immunity changes in aging: relative importance of cell subpopulation switches and of nutritional factors. Immunology Letters 40, 235-242.

Lesourd BM, Moulias R, Favre-Berrone M \& Rapin CH (1992) Nutritional influences on immune responses in elderly. In Nutrition and Immunology, pp. 211-223 [RK Chandra, editor]. St John's, Canada: ARTS Biomedical.

Lewis VM, Twomey JJ, Bealmer P, Goldstein G \& Good RA (1978) Age, thymic involution and circulating thymic hormone activity. Joumal of Clinical Endocrinology and Metabolism 47, 145-150.

Ligthart GJ, Corberand JX, Fournier C, Galanaud P, Hijmans W, Kennes B, Muller-Hermelink HK \& Steinmann GG (1984) Admission criteria for immunogerontological studies in man: the Senieur protocol. Mechanism of Ageing and Development 28 , 47-55.

Ligthart GJ, Radl J, Corberand JX, Van NieuwKoop JAV, Van Stanalduinen GJ, Ducos J, Van Helmond W \& Hijmans W (1990) Monoclonal gammopathies in human aging: increased occurrence with age and correlation with health status. Mechanism of Ageing and Development 52, 235-243.

Ligthart GJ, Van Vlokhoven PC, Schuit HRE \& Hijmans W (1986) The expanded null cell compartment in ageing: increase in the number of natural killer cells and changes in T-cell and NK-cells subset in human blood. Immunology 59, 353-357.

Lucey DR, Clerici M \& Shearer GM (1996) Type 1 and type 2 cytokine dysregulation in human infectious, neoplastic and inflammatory diseases. Clinical Microbiological Reviews 9 , 532-562.

McBean AM, Babish JD, Warren JL \& Melson EA (1993) The effects of influenza epidemics on the hospitalization of persons 65 years and older. In Options for the Control of Influenza, vol. 2, pp. 25-36 [C Hannoun, editor]. Amsterdam: Elsevier.

McConkney DJ, Hartzell P, Chow SC, Orrenius S \& Jondal M (1990) Interleukin 1 inhibits $T$ cell receptor-mediated apoptosis of immature thymocytes. Joumal of Biological Chemistry 265, 3009-3011.

McMurray DN (1998) Impact of nutritional deficiencies on resistance to experimental pulmonary tuberculosis. Nutrition Reviews 56, S147-S152.

Mackall CL \& Gress RE (1997) Thymic aging and T-cell regeneration. Immunological Reviews 160, 91-102.

Makinodan T \& Kay MMB (1980) Age influence on the immune system. Advances in Immunology 29, 287-330.

Manoussakis MN, Tzioufas AG, Silis MP, Pange PJE, Evenos J \& Moutsopoulos HM (1987) High prevalence of anti cardiolipin and other auto antibodies in a healthy elderly population. Immunology 69, 557-565.

Mazari L \& Lesourd B (1998) Nutritional influences on immune response in healthy aged persons. Mechanism of Ageing and Development (In the Press).

Mbawuike IN, Acuna CL, Walz KC, Atmar RL, Greenberg SB \& Couch RB (1997) Cytokines and impaired CD8+ CTL activity among elderly persons and the enhancing effect of IL-12. Mechanism of Ageing and Development 94, 25-39.

Meydani SN, Barklund MP, Lui S, Meydani N \& Miller RA (1990) Vitamin E supplementation enhances cell-mediated immunity in healthy elderly. American Journal of Clinical Nutrition 52, 557-563.

Meydani SN, Wu D, Santos MS \& Hayek MG (1995) Antioxidants and immune response in aged persons: overview of the present evidence. American Journal of Clinical Nutrition 62, Suppl., 1462S-1476S.

Miller RA, Garcia G, Kirk CJ \& Witkowski JM (1997) Early activation defects in $T$ lymphocytes from aged mice. Immunological Reviews 160, 79-90.

Monget AM (1992) Effet de la supplémentation en vitamines antioxydantes (beta carotène, vitamines $\mathrm{C}$ et $\mathrm{E}$ ) et/ou en oligo éléments antioxydants (zinc et sélenium) sur l'immunité, la résistance aux infections, la morbidité et la mortalité chez le sujet âgé institutionnalisé: relations avec le métabolisme des radicaux libres (Effect of antioxidant supplementation using a combination of vitamins ( $\beta$-carotene, vitamins $C$ and E) and/or trace-elements (zinc and selenium) on immunity, infection evolution, morbidity and mortality in institutionalized 
old patients: relationships with free-radical metabolism). $\mathrm{PhD}$ Thesis, Université de Paris VII.

Monget AL, Richard MJ, Cournot MP, Arnaid J, Galan P, Preziosi P, Hercberth B, Favier A, Hercberg $\$$ \& the Gériatrie Min. Vit. Aox Network (1996) Effect of 6 months supplementation with different combinations of an association of antioxidant nutrients on biochemical parameters and markers of the antioxidant defence system in the elderly. European Joumal of Clinical Nutrition 50, 443-449.

Mosmann TR \& Coffman RL (1989) Th1 and Th2 cells: different patterns of lymphokine secretion lead to different functional properties. Annual Review of Immunology 7, 145-173.

Moulias R, Devillechabrolle A, Congy F, Wang A, Marescot M \& Lesourd B (1985a) Low prealbumin: a correlate of immunodeficiency in elderly patients. In Nutrition, Immunity and Illness in the Elderly, pp. 165-172 [RK Chandra, editor]. London: Pergamon Press.

Moulias R, Devillechabrolle A, Lesourd B, Proust J, Marescot MR, Doumerc S, Favre-Berrone M, Congy F \& Wang A (1985b) Respective roles of immune nutritional factors in the priming of the immune responses in the elderly. Mechanism of Ageing and Development 31, 3-137.

Moulias R, Lesourd B, Mélani M, Thiollet M, Deslandes D \& Nafziger J (1988) T lymphocytes subsets changes during bacterial infections in the elderly. In Trends in Biomedical Gerontology, vol. 1, pp. 179-180 [E Steinhagen-Thiessen and DL Knook, editors]. New York: Pergamon Press.

Moulias R, Meaume S, Salvatore R, Faucher-Chabert N \& Lesourd B (1993) Immunité, nutrition et infection respiratoire chez le sujet âgé (Immunity, nutrition and lung infections in aged subjects). Médecine et Hygiène 51, 2498-2502.

Mountz JD \& Hsu H-C (1997) Clinical features associated with correction of T-cell senescence: increased acute-phase response amyloidosis and arthritis. Developmental and Comparative Immunology 21, 509-523.

Mowe W, Behmer T \& Kindt E (1994) Reduced nutritional status in an elderly population $(>70 y)$ is probable before disease and possibly contributes to the development of disease. American Journal of Clinical Nutrition 59, 317-324.

Munoz C, Arévalo M, Lopez L \& Schlesinger L (1994) Impaired interleukin- 1 and tumor necrosis factor production in proteincalorie malnutrition. Nutrition Research 14, 347-352.

Murasko DM, Nelson BS, Silver R, Matour D \& Kaye D (1986) Immunologic response in an elderly population with a mean age of 85. American Journal of Medicine 81, 612-618.

Murasko DM, Weiner P \& Kaye D (1987) Decline in mitogen induced proliferation of lymphocytes with increasing age. Clinical Experimental Immunology 70, 440-448.

Mysliwska J, Bryl E, Foerster J \& Myslinski A (1998) Increase of interleukin 6 and decrease of interleukin 2 production during the ageing process are influenced by the health status. Mechanism of Ageing and Development 100, 313-328.

Nafziger J, Bessege JP, Guillosson JJ, Damais C \& Lesourd B (1993) Decreased capacity of IL-1 production by monocytes of infected elderly patients. Aging, Immunology and Infectious Diseases 4, 25-34.

Nagel JE, Chopra RK, Chrest FJ, McCoy MT, Schneider EL, Holbrook NJ \& Adler WH (1988) Decreased proliferation interleukin 2 synthesis and interleukin 2 receptor expression are accompanied by decreased mRNA expression, in phytohemagglutinin-stimulated cells from elderly donors. Journal of Clinical Investigation 81, 1096-1102.

Nagelkerken L, Hertogh-Huijbregts A, Dobber R \& Dräger A (1991) Age-related changes in lymphokine production related to a decreased number of CD45Rbohi CD4+ T cells. European Joumal of Immunology 21, 273-281.
Nakayama KI, Nakayama K, Negishi I, Kuida K, Louie MC Kanagawa O, Nakauchi H \& Loh DY (1994) Requirement for $\mathrm{CD} 8$ beta chain in positive selection of $\mathrm{CD} 8$ lineage $\mathrm{T}$ cells. Science 263, 1131-1133.

Openshaw P, Murphy EE, Hosken NA, Maino V, Davis K, Murphy K \& O'Garra A (1995) Heterogeneity of intracellular cytokine synthesis at the single-cell level in polarized $\mathrm{T}$ helper $\mathrm{I}$ and $\mathrm{T}$ helper 2 populations. Journal of Experimental Medicine 182, 1357-1364.

Payente H, Rola-Pleszczynski M \& Ghadirian P (1990) Nutrition factors in relation to cellular and regulatory immune variables in a free-living elderly population. American Journal of Clinical Nutrition 52, 927-932.

Penn ND, Purkins L, Kelleher J, Heartley RV, Masie-Taylor BH \& Belfield PW (1991) The effect of dietary supplementation with vitamins $A, C$ and $E$ on cell-mediated immune function in elderly long-stay patients: a randomized, controlled trial. Age and Aging 20, 169-174.

Phair JP (1988) Infections in the elderly. In Infectious Diseases in the Elderly, pp. 6-17 [BA Cunha, editor]. Littleton, MA: PSG Publishing.

Phelouzat MA, Arbogast A, Laforge T, Quadri RA \& Proust JJ (1996) Excessive apoptosis of mature $T$ lymphocytes is a characteristic feature of human immune senescence. Mechanism of Ageing and Development 88, 25-38.

Pike J \& Chandra RK (1995) Effect of vitamin and trace element supplementation on immune indices in healthy elderly. International Journal of Vitamin and Nutrition Research 65, 117-121.

Pompidou A, Duchet N, Cooper MD, Mace B, Telvi L, Coutance F, Hadden JW \& Renoux G (1985) The generation and regulation of human $T$ lymphocytes by Imuthiol. Evidence from an in vitro differentiation induction system. International Journal of Immunopharmacology 7, 561-566.

Proust J, Moulias R, Fumeron F, Beckkhoucha F, Bussone M, Schimd M \& Hors J (1982) HLA and longevity. Tissue Antigens 19, 168-173.

Proust J, Rosenzweig P, Debouzy C \& Moulias R (1985) Lymphopenia induced by acute bacterial infections in the elderly: a sign of age-related immune dysfunction of major prognostic significance. Gerontology 31, 178-185.

Rabinowich H, Goses Y, Reshef T \& Klajman A (1985) Interleukin 2 production and activity in aged humans. Mechanism of Ageing and Development 32, 213-226.

Robine JM \& Mormiche P (1993) L'Espérance de Vie sans Incapacité Augmente (Increasing Life Expectancy without Handicaps). INSEE Publication no. 281. Paris: INSEE.

Roche AF (1994) Sarcopenia: a critical review of its measurement and health-related significance in the middle-aged and elderly. American Journal of Human Biology 6, 33-42.

Rosenthal AJ, McMurtry CT, Sanders KM, Jacobs M, Thompson D \& Adler RA (1997) The soluble interleukin-2 receptor predicts mortality in older hospitalized men. Journal of the American Geriatrics Society 45, 1362-1364.

Rudman D \& Feller AG (1987) Protein-calorie undernutrition in the nursing home. Journal of the American Geriatrics Society 37, 173-183.

Sanders ME, Maggoba MW, Sharrow SO, Stephany D, Springer TA, Young HA \& Shaw S (1988) Human memory T lymphocytes express increased levels of three cell adhesion molecules (LFA-3, CD2, and LFA-1) and three other molecules (UCHL-1, CDw29 and Pgp-1) and have enhanced IFN- $\gamma$ production. Journal of Immunology 140, 1401-1407.

Scarfiotti C, Fabris F, Cestaro B \& Giuliani A (1997) Free radicals, atherosclerosis, ageing, and related dysmetabolic pathologies: pathological and clinical aspects. European Journal of Cancer Prevention 6, Suppl. 1, S31-S36. 
Scrimshaw N, Taylor CE \& Gordon JE (1988) Interactions of nutrition and infection. Nutrition 4, 13-52.

Segal R, Dayan M, Globerson A, Habut B, Shearer GM \& Mozes E (1997) Effect of aging on cytokine production in normal and experimental system in lupus erythematosus afflicted mice. Mechanism of Ageing and Development 96, 47-58.

Shearer GM (1997) Th1/Th2 changes in ageing. Mechanism of Ageing and Development 94, 1-5.

Sindermann J, Kruse A, Frercks HJ, Schutz RM \& Kirchner H (1993) Investigations of the lymphokine system in elderly individuals. Mechanism of Ageing and Development 70, 149159.

Siveke JT \& Hamann A (1998) Cutting edge: T helper 1 and T helper 2 cells respond differentially to chemokines. Journal of Immunology 160, 550-554.

Spaulding CC, Walford RL \& Effros RB (1997) Calorie restriction inhibits the age-related dysregulation of the cytokines TNF- $\alpha$ and IL-6 in C3B10RF1 mice. Mechanism of Ageing and Development 96, 75-88.

Sprenger MJW, Mulder PGH, Beyer WE \& Masurel N (1991) Influenza: relation of mortality to morbidity parameters, The Netherlands. 1970-1989. Journal of Epidemiology 120, $1118-1124$.

Talbott MC, Miller LT \& Kerkvliet NI (1987) Pyridoxine supplementation: effect on lymphocyte responses in elderly persons. American Joumal of Clinical Nutrition 46, 659-664.

Thoman ML (1997) Effects of the aged microenvironment on CD4+ T cell maturation. Mechanism of Ageing and Development 96, 75-88.

Tosi P, Krart R, Luzy P, Cintorino M, Frankhauser G, Hess MW \& Cottier H (1982) Involution patterns of the human thymus. I. Size of the cortical area as a function of age. Clinical Experimental Immunology 47, 497-503.

Tyan ML (1981) Marrow stem cells during development and aging. In Handbook of Immunology and Aging, pp. 87-102 [MMB Kay and T Makinodan, editors]. New York: CRC Press.

Utsuyama M, Kasai M, Kurashima C \& Hirokawa K (1997) Age influence on the thymic capacity to promote differentiation of $\mathrm{T}$ cells: induction of different composition of $\mathrm{T}$ cells subsets by ageing thymus. Mechanism of Ageing and Development 58, 167177.

Venkatraman JT, Attwood VG, Turturro A, Hart RW \& Fernandes G (1994) Maintenance of virgin T cells and immune functions by food restriction during aging in long-lived B6D2F1 female mice. Aging, Immunology and Infectious Diseases 5, 13-26.

Venkatraman JT \& Fernandes G (1994) Modulation of Aging by Food Restriction. New York: CRC Press.

Volberding PA (1996) Age as a predictor of progression in HIV infection. Lancet 347, 1569-1570.

Wahlquist ML (1990) Vitamins, nutrition, and aging. In Nutrition and Aging: Progress in Clinical and Biological Research, pp. 175-202 [DM Prinsley and HH Sandstead, editors]. New York: Alan R Liss.

Wakikawa A, Utsuyama M \& Hirokawa K (1997) Altered expression of various receptors on $\mathrm{T}$ cells in young and old mice after mitogenic stimulation: a flow cytometric analysis. Mechanism of Ageing and Development 94, 113-122.

Weksler ME (1995) Immune senescence: deficiency or dysregulation. Nutrition Reviews 53, S3-S7.

Welle S, Thornton C \& Jozefowicz R (1993) Myofibrillar protein synthesis in young and old men. American Journal of Physiology 264, E693-E698.

Yarasheski KE, Zachwieja JJ \& Bier DM (1993) Acute effects of resistance exercise on muscle protein synthesis rate in young and elderly men and women. American Journal of Physiology $\mathbf{2 6 5}$, E210-E214.

Yong-Xing M, Yue Z, Zan-Shun W, Chuan-Fu W, Su-Ying C, Mao-Tong Z, Gong-Liang Z, Su-Qin Z, Jian-Gang Z, Qi G \& Lin H (1997) HLA and longevity or aging among Shanghai Chinese. Mechanism of Ageing and Development 94, 191-198.

Young VR (1990) Protein and amino acid metabolism with reference to aging and the elderly. In Nutrition and Aging, pp. 279-300 [DM Prinsley and HH Sandstead, editors]. Amsterdam: Alan R Liss.

Yu S, Abel L \& Globerson A (1997) Thymocyte progenitors and $\mathrm{T}$ cell development in ageing. Mechanism of Ageing and Development 94, 103-111. 